Animal Health Research Institute,

Damanhour Branch.

\title{
DETERMINATION OF LEAD AND CADMIUM LEVELS IN SOME OF FRESH WATER FISH MARKETED IN DAMANHOUR CITY
}

(With 4 Tables)

\section{By}

\section{I.A. EL-KEWAIEY; F.A. AL-TEDAWY and H.R. EL-HOFY}

(Received at 19/7/2011)

\section{تقير مستويات الرصاص والكادميوم فى بعض أسماك المياه العذبة المسوقة بمدينة دمنهور في الكير}

إبراهير على القويعى ، فايزة عبل العزيز التداوى ، هناء رشاد الحوفى

أجريت هذة الدراسة لتقدير تركيز ات الرصاص و الكادميو في ستين عبنة من أسماك المياه

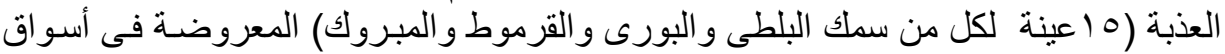

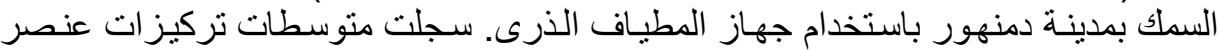

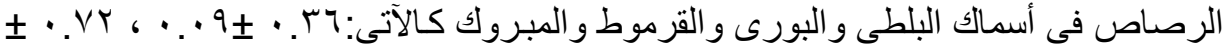

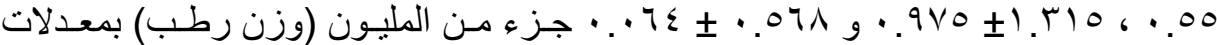

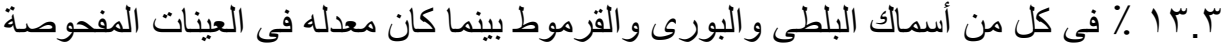

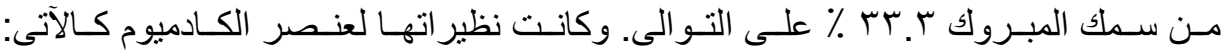
إ.

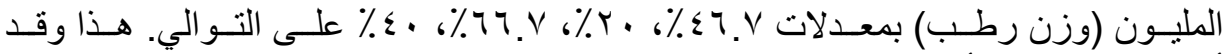

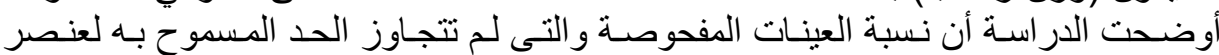

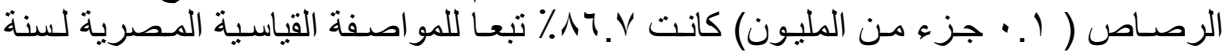

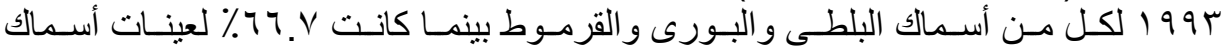

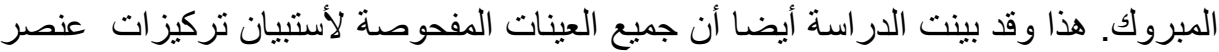

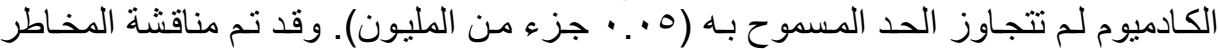

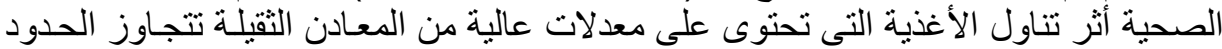

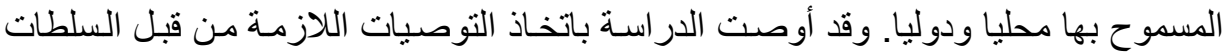
الصحية بشأن مستهلكي الأسماك وكذا الإجراءات الحرات الحكومية للحفاظ على البيئة.

\section{SUMMARY}

Sixty random samples of some fresh water fish species: Tilapia nilotica (Bolti), Mugil cephalus (Bori), Clarias lazera (Karmout) and Cyprinus carpiol (Carp) (15 of each) were collected from fish markets of 
Damanhour city for detection of lead and cadmium levels in their muscular tissues using Perkin-Elmer atomic absorption spectrophotometer. The reported results showed that the mean values of lead in the examined samples of the fore-mentioned fish species were $0.360 \pm 0.090,0.720 \pm 0.550,1.315 \pm 0.975$ and $0.568 \pm 0.064 \mathrm{ppm}$, wet weight with an incidence of $13.3 \%$ to each of Bolti, Bori and Karmout, $33.3 \%$ for Carp. While that of the cadmium were $0.020 \pm 0.005$, $0.019 \pm 0.006,0.016 \pm 0.003$ and $0.014 \pm 0.003 \mathrm{ppm}$ wet weight with incidences of $46.7 \% 20.0 \%, 66.7 \%$ and $40.0 \%$, respectively. The percentages of the examined samples of Bolti, Bori, Karmout and Carp for lead levels which not exceed the permissible limit $(0.1 \mathrm{ppm})$ according to the Egyptian Organization for Standarization and Quality Control "EOSQC" (1993) were 86.7\% for each of Bolti, Bori and Karmout, $66.7 \%$ for Carp and the values of examined samples for cadmium level not exceed the permissible limit $(0.1 \mathrm{ppm})$ according to "EOSQC" (1993). The puplic health significance and the hazardous toxic effects of these heavy metals were discussed. In addition, recommendations regarding the consumption of fish from the health authorities should be taken for protection of fish consumers. The governmental role is to improve the enforcement of the safety, health and environmental laws.

Key words: Heavy metals, lead, cadmium, fish, fresh water fish.

\section{INTRODUCTION}

Fish is a valuable source of high quality protein, polyunsaturated fatty acids, minerals and vitamins constituting the major part of the human diet and it is not surprising that numerous studies have been carried out on metals accumulation in different fish species (Gundacker, 2000; Alam et al., 2002). Water pollution is a critical environmental problem facing public health authorities.Industrial wastes, geochemical structure and mining of metals create a potential source of heavy metals pollution in the aquatic environment (Lee and Stuebing, 1990). Metals such as iron, copper, zinc and manganese are essential as they play an important role in biological systems where lead and cadmium are nonessential metals as they are toxic,even in trace amounts.

Heavy metals are recognized as cumulative toxic substances due to slow elimination rates from the body. Most of these pollutants are toxic and cause serious health hazard to human bing depending on their 
levels of contamination (Farag et al., 2000). Lead and Cadmium are considered as toxic elements due to their competition with the essential metals for binding sites and also their interference with sulfhydryl groups and structural proteins (Ahmed et al., 1993), and the signs of the toxicity depend on the chemical form of the element, the dosage, the route, the frequency and the duration of administration (Underwood, 1977). Lead is linked to encephalopathy in adults and children. The outcome is frequently fatal in children and those who survive often present irreversible neurological and neuropsychological sequelae (ATSDR, 1999) and also long-term exposure to cadmium leads to several morphological changes in the kidneys (Satarug and Moore 2004). In addition, during woman pregnancy led to reduced birth weight and /or premature birth (Henson and Chedrese, 2004).

Heavy metals have a higher tendency to be incorporated into food chains and become accumulated in tissues and organs of fish and other aquatic organisms in concentrations higher than those in water, and this represents serious health hazards to consumers (Draz et al., 1993).

The present study was conducted to determine the levels of lead and cadmium pollution of commen fresh water fish species marketed in Damanhour city.

\section{MATERIALS and METHODS}

\section{A. Collection of samples:}

Sixty random fresh-water fish samples of different species (15 each of Tilapia nilotica, Mugil cephalus, Clarias lazera and Cyprinus carpiol) were collected randomly at the consumer level from different fish markets of Damanhour city in El-Boheira governorate during summer of 2010 and each sample was wrapped in a light polyethylene bag placed in ice and taken to the laboratory without delay for analysis of lead $(\mathrm{Pb})$ and cadmium $(\mathrm{Cd})$ levels.

\section{B. Preparation of collected samples:}

The collected fish species were washed with tape water several times to remove slime and mud and then with de-ionized water. The samples of each specie taken from the muscles below the dorsal fin and at the middle line were homogenized and kept at fresh polyethylene bags at $-20 \circ \mathrm{C}$ for analysis. A measured weight (1gm) was transferred into clean and acid washed scrow-capped digestion tubes. All digestion tubes were identified for examination.

\section{Digestion procedure:}


Each prepared fish sample was digested according to Tsoumbaris and Papadopoulou (1994). 10ml of mixture of concentratednitric and perchloric acids (1vol.:1vol.) were added to each sample. The tubes were closed and the contents were vigorously shaken and allowed to stand over-night to be cold digested followed by mild increase in temperature till heating to $100{ }^{\circ} \mathrm{C}$ in a water bath for 3-4 hours to ensure complete digestion of all samples.4-5 drops of hydrogen peroxide $30 \%$ were added to each sample and continue heating process till the brown nitrous gases were expelled and the mixtures become clear. After cooling, each digest was diluted to $25 \mathrm{ml}$ with deionized water and filterated through Whatman filter paper No.42. The clear filtrate of each sample was kept in refrigerator to avoid evaporation. All samples and blank solutions were analysed by using Flame Atomic Absorption Spectrophotometry "AAS" (Perkin-Elmer Atomic Absorption Spectrophotometry model 2380, USA) for determination of lead and cadmium concentrations.

Parameters for instrumental instructions of Atomic Absorption Spectrophotometry

\begin{tabular}{|l|c|c|c|c|c|c|}
\hline Metal & $\begin{array}{c}\text { Lamp wave } \\
\text { Length } \\
(\mathrm{nm})\end{array}$ & $\begin{array}{c}\text { Slit width } \\
(\mathrm{nm})\end{array}$ & $\begin{array}{c}\text { Lamp } \\
\text { Current (ma) }\end{array}$ & $\begin{array}{c}\text { Fuel flow } \\
\text { Rate(1/min.) }\end{array}$ & $\begin{array}{r}\text { Burner } \\
\text { height } \\
(\mathrm{cm})\end{array}$ & $\begin{array}{c}\text { Detection } \\
\text { limit }\end{array}$ \\
\hline Lead $(\mathrm{Pb})$ & 217 & 0.7 & 12 & 30 & 8 & $0.02 \mathrm{ppm}$ \\
\hline $\begin{array}{l}\text { Cadmium } \\
(\mathrm{Cd})\end{array}$ & 228.8 & 0.7 & 5 & 30 & 8 & $\begin{array}{c}0.0006 \\
\mathrm{ppm}\end{array}$ \\
\hline
\end{tabular}

D.Quantitive determination of heavy metals in the examined samples:

The concentrations of $\mathrm{Pb}$ and $\mathrm{Cd}$ in the examined samples were calculated according to the following equation: $\mathrm{C}=\mathrm{R} \times \mathrm{D} / \mathrm{W}$

Where: $\mathrm{C}=$ Concentration of heavy metals $(\mathrm{mg} / \mathrm{kg})$ wet weight.

$\mathrm{R}=$ Reading of element concentration on digital scale of AAS.

$\mathrm{D}=$ Final volume of prepared sample in mls.

$\mathrm{W}=$ Weight of the wet sample.

The reading results of the absorbance values of $\mathrm{Pb}$ and $\mathrm{Cd}$ concentrations were recorded. 


\section{RESULTS}

Table 1: Lead concentrations ( $\mathrm{mg} / \mathrm{kg}$,wet weight) in the examined fish samples ( $\mathrm{n}=15$ of each).

\begin{tabular}{|c|c|c|c|c|c|}
\hline \multirow{2}{*}{ Fish specie } & \multicolumn{2}{|c|}{ Examined samples } & \multirow[t]{2}{*}{ Minimum } & \multirow[t]{2}{*}{ Maximum } & \multirow[t]{2}{*}{$\operatorname{Mean} \pm \mathrm{SEM}$} \\
\hline & $\mathrm{NO}$ of $+\mathrm{ve}$ & $\%$ & & & \\
\hline $\begin{array}{l}\text { Tilapia } \\
\text { nilotica }\end{array}$ & 2 & 13.3 & 0.27 & 0.45 & $0.36 \pm 0.09$ \\
\hline $\begin{array}{l}\text { Mugil } \\
\text { cephalus }\end{array}$ & 2 & 13.3 & 0.17 & 1.27 & $0.72 \pm 0.55$ \\
\hline $\begin{array}{l}\text { Clarias } \\
\text { lazera }\end{array}$ & 2 & 13.3 & 0.34 & 2.29 & $1.315 \pm 0.975$ \\
\hline $\begin{array}{l}\text { Cyprinus } \\
\text { carpiol }\end{array}$ & 5 & 33.3 & 0.41 & 0.79 & $0.568 \pm 0.064$ \\
\hline
\end{tabular}

Table 2: Cadmium concentrations ( $\mathrm{mg} / \mathrm{kg}$,wet weight) in the examined fish samples( $n=15$ of each)

\begin{tabular}{|c|c|c|c|c|c|}
\hline \multirow{2}{*}{ Fish specie } & \multicolumn{2}{|c|}{ Examined samples } & \multirow{2}{*}{ Minimum } & Maximum & Mean \pm SEM \\
\cline { 2 - 5 } & NO of $+\mathrm{ve}$ & $\%$ & & 0.041 & $0.020 \pm 0.005$ \\
\hline Tilapia nilotica & 7 & 46.7 & 0.005 & 0.029 & $0.019 \pm 0.006$ \\
\hline Mugil cephalus & 3 & 20.0 & 0.008 & 0.034 & $0.016 \pm 0.003$ \\
\hline Clarias lazera & 10 & 66.7 & 0.002 & 0.026 & $0.014 \pm 0.003$ \\
\hline Cyprinus carpiol & 6 & 40.0 & 0.001 & & \\
\hline
\end{tabular}

- SEM = standard error of the mean. -Negative samples were under detectable limit of AAS.

- $\mathrm{mg} / \mathrm{kg}=\mathrm{ppm}=\mu \mathrm{g} / \mathrm{g}$. - +ve: samples within detectable limit of AAS. 
Table 3: Frequency distribution of lead and cadmium levels in the examined samples according to the permissible limits of EOSQC (1993)

\begin{tabular}{|c|c|c|c|c|c|c|}
\hline \multirow{2}{*}{$\begin{array}{l}\text { Heavy } \\
\text { Metal }\end{array}$} & \multirow{2}{*}{$\begin{array}{c}\text { Fish } \\
\text { Samples }\end{array}$} & \multirow{2}{*}{$\begin{array}{l}\text { Permissible } \\
\text { Limit } *\end{array}$} & \multicolumn{2}{|c|}{$\begin{array}{l}\text { More than the } \\
\text { Permissible limit }\end{array}$} & \multicolumn{2}{|c|}{$\begin{array}{l}\text { Less than the } \\
\text { Permissible limit }\end{array}$} \\
\hline & & & NO. & $\%$ & NO. & $\%$ \\
\hline \multirow[t]{4}{*}{ Lead } & Tilapia nilotica & \multirow{4}{*}{$0.1 \mathrm{mg} / \mathrm{kg}$} & 2 & 13.3 & 13 & 86.7 \\
\hline & Mugil cephalus & & 2 & 13.3 & 13 & 86.7 \\
\hline & Clarias lazera & & 2 & 13.3 & 13 & 86.7 \\
\hline & Cyprinus carpiol & & 5 & 33.3 & 10 & 66.7 \\
\hline \multirow[t]{4}{*}{ Cadmium } & Tilapia nilotica & \multirow{4}{*}{$0.1 \mathrm{mg} / \mathrm{kg}$} & 0 & 0 & 15 & 100.0 \\
\hline & Mugil cephalus & & 0 & 0 & 15 & 100.0 \\
\hline & Clarias lazera & & 0 & 0 & 15 & 100.0 \\
\hline & Cyprinus carpiol & & 0 & 0 & 15 & 100.0 \\
\hline
\end{tabular}

*The permissible limit according to Egyptian Organization for Standardization and Quality Control "EOSQC , 1993"

Table 4: Estimated daily and weekly intakes of adult person consuming fresh water fishes and the comparison with the recommended National and International permissible tolerable limits in foods.

\begin{tabular}{|c|c|c|c|c|c|c|}
\hline \multirow[t]{2}{*}{ Metal } & \multicolumn{2}{|c|}{$\begin{array}{c}\text { Concentration } \\
\text { level in examined } \\
\text { samples }(\mu \mathrm{g} / \mathrm{g})\end{array}$} & \multirow{2}{*}{$\begin{array}{c}\text { EWI } \mu \mathrm{g} / \text { adult }^{\text {a }} \\
\text { person }^{\mathrm{a}} \\
(\mathrm{EWI} \mu \mathrm{g} / \mathrm{kg} \\
\text { b. w.) }\end{array}$} & \multirow{2}{*}{$\begin{array}{c}\text { Provisional } \\
\text { Permissible } \\
\text { Tolerable } \\
\text { Weekly } \\
\text { Intakes (PTWI) } \\
{\text { ( } \mu \mathrm{g} / \mathrm{kg}, \mathrm{b} . w .)^{\mathrm{b}}}\end{array}$} & \multirow{2}{*}{$\begin{array}{c}\text { Permissible } \\
\text { Tolerable daily } \\
\text { Intakes(PTDI) } \\
\text { " } \mu \mathrm{g} / \mathrm{day} / 60 \mathrm{~kg}, \mathrm{~b} . w . " \\
\text { (PTDI, } \mu \mathrm{g} / \mathrm{kg}, \text { b.w.) }^{\mathrm{b}}\end{array}$} & \multirow{2}{*}{$\begin{array}{c}\text { Human } \\
\text { Weekly } \\
\text { intake of } \\
\text { Heavy metals } \\
\text { "EOSQC" } \\
(1993)\end{array}$} \\
\hline & $\begin{array}{l}\text { Examined } \\
\text { samples }\end{array}$ & $\begin{array}{c}\text { Mean } \\
(\mu \mathrm{g} / \mathrm{g})\end{array}$ & & & & \\
\hline \multirow{4}{*}{$\mathrm{Pb}$} & Bolti & 0.360 & $122.4(2.04)$ & \multirow{4}{*}{25} & \multirow{4}{*}{$214.3(3.57)$} & \multirow{4}{*}{$\begin{array}{c}50 \\
\mu \mathrm{g} / \mathrm{kg} \\
\text { Body } \\
\text { weight }\end{array}$} \\
\hline & Bori & 0.720 & $244.8(4.08)$ & & & \\
\hline & Karmout & 1.315 & $447.1(7.45)$ & & & \\
\hline & Carp & 0.568 & $193.12(3.22)$ & & & \\
\hline \multirow[t]{4}{*}{$\mathrm{Cd}$} & Bolti & 0.020 & $6.8(0.113)$ & & \multirow{4}{*}{$60(1.0)$} & \multirow{4}{*}{$\begin{array}{c}6.7-8.3 \\
\mu \mathrm{g} / \mathrm{kg} \\
\text { Body } \\
\text { weight }\end{array}$} \\
\hline & Bori & 0.019 & $6.46(0.11)$ & & & \\
\hline & Karmout & 0.016 & $5.44(0.09)$ & & & \\
\hline & Carp & 0.014 & $4.76(0.08)$ & & & \\
\hline
\end{tabular}

${ }^{\mathrm{a}} \mathrm{EWI}$ :estimated weekly intakes from consumption of 12 ounces (approximately 340 grams) of fish every week by adult person of $60 \mathrm{~kg}$ body weight according to US EPA(2004).

- Values in parenthesis calculated as weekly intake to every kg body weight.

- $\mu \mathrm{g}$ :microgram $=0.001$ milligram (mg). b.w.:body weight

${ }^{b}$ Joint FAO/WHO Expert Committee on Food Additives(2004). 


\section{DISCUSSION}

Several reports describe metals residues in fish from both aquatic and marine species (Yess, 1993; Abou-Arab et al., 1996; Atta et al., 1997) but the concentrations in their tissues vary considerably among different studies possibly due to differences in metal concentrations and chemical characteristics of water from which fish were caught, ecological needs, metabolism and feeding patterns of fish.

\section{Lead (Pb):}

Lead causes haematological, gastrointestinal and neurological dysfunctions. Prolonged exposure to $\mathrm{Pb}$ may cause also chronic nephropathy, hypertension and reproductive impairment. In addition, $\mathrm{Pb}$ inhibits enzymes, alters cellular calcium metabolism and slows nerve conduction (Elinder, 1985). Children under 6 years are especially susceptible to the adverse effects of $\mathrm{Pb}$ for several reasons. These include their behavioral characteristics (outdoor activity, less concern for hygienic conditions, hand-to-mouth activities), their higher disposition for lead absorption and the prevalence of nutritional deficiencies (e.g. iron and vitamin $\mathrm{D}$ ) among children that enhance absorption of $\mathrm{Pb}$ from the gastrointestinal tract. As the blood-brain barrier is not yet fully developed in young children, hematological and neurological adverse effects of $\mathrm{Pb}$ occur at lower threshold levels than in adults (Air Quality Guidelines for Europe, 2000).

The results obtained in Table 1, showed that the mean values of lead in examined samples of T.nilotica (Bolti), M.cephalus (Bori), Clarias lazera (Karmout) and Cyprinus carpiol (Carp) were $0.360 \pm$ $0.090,0.720 \pm 0.550,1.315 \pm 0.975$ and $0.568 \pm 0.064 \mathrm{mg} / \mathrm{kg}$,wet weight,with incidence of $13.3 \%$ for each of Bolti, Bori and Karmout but was $33.3 \%$ for Carp.

These results were agreed with that of El-Atabany (1995) who recorded that the levels of $\mathrm{Pb}$ levels in muscles tissue of T.nilotica and M.cephalus were $0.35 \pm 0.02$ and $0.38 \pm 0.01 \mathrm{mg} / \mathrm{kg}$,wet weight. ElKelish-Hoda (1995) reported that means of $\mathrm{Pb}$ levels in muscles tissues of T. nilotica and Carp fish caught freshly from Abbassa fish farm as $0.31 \pm 0.04$ and $0.33 \pm 0.05 \mathrm{ug} / \mathrm{g}$,wet weight, also Abd El-Aziz (1996) recorded that T.nilotica in Gharbia governorate contained $0.628 \mathrm{ppm} \mathrm{Pb}$. Labib et al. (2008) found that the $\mathrm{Pb}$ concentrations were ranged from 0.12 to $0.53 \mathrm{ppm}$, wet weight in T.nilotica and C.lazera collected from five districts of Qena governorate, Upper Egypt. 
Nearly the same results were registerated by Abd El-Kader et al. (1993) where lead concentrations in M.cephalus were ranged from 0.29 to $0.42 \mathrm{ug} / \mathrm{g}$ wet weight and attributed these levels to possible pollution through agricultural and industrial re-sources at Assuit governorate.

Higher results were recorded by Abou-Donia (1990) (1.662 ppm) and Abd El-Fatah and Salem (2007) who reported that Pb levels in T.nilotica and M.cephalus collected from Giza markets were 1.015 0.500 and $1.80 \pm 0.61 \mathrm{ppm}$ and in samples collected from Cairo markets were $1.10 \pm 0.84$ and $1.90 \pm 1.01 \mathrm{ppm}$, respectively.

The percentages of examined fish samples which was less than the lead permissible limit $(0.1 \mathrm{mg} / \mathrm{kg})$ according to Egyptian Organisation for Standarization and Quality Control "EOSQC" (1993) were $86.7 \%$ for each of Bolti, Bori and Karmout, and $66.7 \%$ for Carp (Table, 3). Since the United States Environmental Protection Agency (EPA, 1999) has never established a reference dose (RfD), a definitive level cannot be asserted for $\mathrm{Pb}$ in fish. The advisory limit would likely be $1 \mathrm{ppm}$ or greater. Hodson et al. (1984) indicated that the Canadian $\mathrm{Pb}$ limit of $10 \mathrm{ppm}$ was discontinued, but that the british limit remains at 2 ppm in fish, fish paste and canned fish (5 ppm in fried and salted fish). Abou-Arab et al. (1996) indicated that the FAO limit (1983) was 2.0 ppm.

The calculated weekly intake of lead $(\mathrm{Pb})$ estimated by $\mu \mathrm{g} / \mathrm{kg}$,b.w. for adult person of $60 \mathrm{~kg}$ body weight in this study from eating 12 ounces (approximately $340 \mathrm{~g}$ ) of each Bolti, Bori, Karmout and Carp fish according to US EPA (2004) were 2.04, 4.08, 7.45 and 3.22, respectively (Table, 4). These values were lower than the maximum provisional tolerable weekly intake (PTWI) of lead for human stipulated by "E.O.S.Q.C. (1993) which is $50 \mu \mathrm{g} / \mathrm{kg}$ body weight. In 1993, the Joint FAO/WHO Expert Committee for Additives and Contaminants (JECFA) reduced the value it had provisionally specified for adults in 1972 , for tolerable lead consumption per week (PTWI) from $0.05 \mathrm{mg} / \mathrm{kg}$ B.W. to $0.025 \mathrm{mg}(25 \mu \mathrm{g})$. The reasons for reduction may be due to, firstly, that research has revealed further harmful potentials in lead and, secondly, that lead contamination has decreased throughout the world.

\section{Cadmium (Cd):}

The major route of exposure to $\mathrm{Cd}$ for non-smoking general population is via food, the contribution from other pathways to total uptake is small (Goyer, 1991). The International Agency for Research on Cancer (IARC) classifies $\mathrm{Cd}$ as Class1 "The agent (mixture) is carcinogenic to humans" (Stanley, 2004). Cadmium, like lead, is a 
cumulative poison, i.e. the danger lies primarily in the regular consumption of foodstuffs with low contamination. However, in contrast to lead, the definition of an exact toxicity limit is not possible for cadmium. Although the absorption of $\mathrm{Cd}$ is low from gastrointestinal tract, it has a long biological half-life due to the cumulative effect.

The result recorded in Table 2 revealed that the means of cadmium concentrations in examined samples of Bolti, Bori, Karmout and Carp fish were $0.020 \pm 0.005,0.019 \pm 0.006,0.016 \pm 0.003$ and $0.014 \pm 0.003 \mathrm{mg} / \mathrm{kg}$ wet weight, with incidences of $46.7 \%, 20.0 \%$, $66.7 \%$ and $40.0 \%$, respectively.

This result agree with El-Nabawi et al. (1987) who reported that the cadmium level in the examined muscles tissues of T.nilotica hunted from Abo-Qir bay,Edku,Maruit lakes was ranged from 0.018 to 0.023 ug/g, El-Atabany (1995) which recorded that the means of Cd levels in muscles samples of T.nilotica and M.cephalus fishered from Al-Manzala lake were $0.09 \pm 0.01$ and $0.07 \pm 0.01 \mathrm{mg} / \mathrm{kg}$ wet weight, respectively. Nearly similar results of $\mathrm{Cd}$ levels in muscles of T.nilotica and Carp caught freshly from Abbassa fish farm were reported by El-kelish-Hoda (1995).

While higher figures were obtained by Abd El-Fatah and Salem (2007) who revealed that the mean values of $\mathrm{Cd}$ in T.nilotica and Mugil cephalus collected from Giza and Cairo were $0.85 \pm 0.11,1.09 \pm 0.416$ and $2.0 \pm 0.92,2.51 \pm 1.51 \mathrm{ppm}$, respectively. Also, Labib et al. (2008) found that the $\mathrm{Cd}$ concentration was ranged from 0.32 to $0.42 \mathrm{ppm}$ wet weight of examined samples of T.nilotica and C.lazera.

Table 3 declared that the frequency distribution of cadmium in examined samples of each fish species not exceed the permissible limit (0.1ppm)according to "EOSQC" (1993). The levels of Cd were below the Risk-Based Concentration (RBC)of $1.4 \mathrm{ppm}$ according to United states Environmental Protection Agency (EPA, 1999). However, Gutenmann et al. (1988) indicated that a frequently used food safety limit for $\mathrm{Cd}$ in food is $2.0 \mathrm{ppm}$, while by Food and Agriculture Organization (FAO) at (1983) was $0.5 \mathrm{ppm}$. Moreover, the estimated weekly intakes $(\mu \mathrm{g} / \mathrm{kg}, \mathrm{b} . \mathrm{w}$.$) of \mathrm{Cd}$ from consumption of $340 \mathrm{~g}$ of each Bolti, Bori, Karmout and Carp fish were lower than the maximum provisional tolerable weekly intake (PTWI) of $\mathrm{Cd}$ stipulated by "E.O.S.Q.C. (1993) and the Joint FAO/WHO Expert Committee for Additives and Contaminants "JECFA" (2004) (Table 4).

Finally,the heavy metals in fresh water fish were attributed to channel water pollution and to the cumulative effects of such metals. It 
was very difficult to compare the metals concentrations even within the similar tissues of two different species because of different feeding habits, the difference in the aquatic environments concerning the source and level of water pollution (Papagiannis et al., 2004), growing rates of the species, types of tissues analysed. Using the FAO/WHO (Anonymous, 2003) values of the provisional tolerable weekly intakes of $\mathrm{Pb}$ and $\mathrm{Cd}(25$ and $7 \mathrm{ug} / \mathrm{g}$ ) for a $60 \mathrm{~kg}$ adult person were estimated to be 1500 and $420 \mu \mathrm{g} /$ person/ week, respectively. The mean concentration of $\mathrm{Pb}$ from consumption of Bolti, Bori, Karmout and Carp fish in this study were $0.36,0.72,1.315$ and $0.568 \mathrm{mg} / \mathrm{kg}$, respectively, and therefore, an adult man of $60 \mathrm{~kg}$ body weight could safely consume 4.16, 2.08, 1.14 or $2.64 \mathrm{~kg}$ fish meat weekly.

It could be concluded that the incidences and levels of $\mathrm{Pb}$ and $\mathrm{Cd}$ were almost low and so that the daily and weekly intakes were consequently were not exceeding the national and international permissible limits of human food. Advisory actions should be warned the at-risk populations like children, pregnant and/or lactating women to avoid over consumption of fish. More governmental efforts still be needed and a powerful law incriminate the environmental pollution should be issued.

\section{REFERENCES}

Abd El-Aziz, A.A.H. (1996): Studies on heavy metals contaminating fresh water fish in Gharbia governorate in Egypt. Ph.D. Vet. Thesis, Moshtohor, Zagazig Universty, Benha Branch.

Abd El-Fatah, Noha, R.M. and Salem, Ghada, S.E. (2007): Heavy metal residues in some fresh Egyptian fishes. Vet. Med. J., Giza. 55, 3: 7787-798.

Abd El-Kader, M.A.; Tark, I.Y.; Amine, M.A. and Aref, M.A. (1993): Heavy metal pollution in fish ponds. Zag. Vet. J., 21(2): 116-125.

Abou-Arab, A.A.K.; Ayesh, A.M.; Amra, H.A. and Naguib, K. (1996): Charactteristic levels of some pesticides and heavy metals in imported fish. Food Chemistry, 57(1): 1-6.

Abou-Donia, M.A. (1990): Selected devised techniques for detecting fish contaminants. Ph.D. Agri. Ain-Shams Univ.

Ahmed, F.E.; Wolke, D. and Steinman, D. (1993): Risk assessment and managment of chemical contaminants in fishery products consumed in U.S.A. J. Applied Toxicol., 13 (6): 395-410. 
Alam, M.G.M.; Tanaka, A.; Allinson, G.; Laurenson, L.J.B.; Stagnitti, F. and Snow, E. (2002): A comparison of trace element concentrations in cultured and wild carp (Cyprinus carpio) of lake Kasumigaura, Japan. Ecotoxicology and Environmental Safety, 53: 348-354.

Air Quality Guidelines for Europe (2000): WHO Regional Publications, European Series, No. $912^{\text {nd }}$ Ed. 288 pp.

Anonymous (2003): Joint FAO/WHO expert committee on food additives. Sixty-first Meeting Rome, June 10-19.

ATSDR "Agency for Toxic Substances and Disease Registry" (1999): Toxicological profile for lead. Atlanta, GA: U.S. Department of Health and Human Services, Public Health Service.

Atta, M.B.; El-Sebaie, L.A.; Noaman, M.A. and Kassab, H.E. (1997): The effects of cooking on the content of heavy metals in fish (Tilapia nilotica). Food Chmistry 58 (1-2): 1-4.

Draz, A.; Samaaha, I.; El-Telbany, M. and El-Sarhaa, M. (1993): Effect of chronic exposures to copper on production and total residues among Tilapia species. Bull. Nat. Inst. Oen. Fish, 19: 351-362.

El-Atabany, A.I. (1995): Cadmium and Lead residues in some Food Animals and fish tissues at Manzala, Dakhalia. Zag. Vet. J. 23, 5: $90-96$.

Elinder, C.G. (1985): "Cadmium: Uses, Occurrence and Intake in Cadmium and Health." A Toxicological and Epidemiological Appraisal, Volume 1, pp 23-36.

El-Kelish-Hoda, I. (1995): Lead and cadmium residues in some food animals and fish at Zagazig city. Zag. Vet. J. 23, 5: 97-101.

El-Nabawi, A.; Heinzow, B. and Kiruse, H. (1987): As, Cd, Cu, Pb, $\mathrm{Hg}$ and $\mathrm{Zn}$ in fish from Alexandria region, Egypt. Bull. Environ. Contam. Toxico., 39: 889-897.

EPA. (1999): EPA region III Risk-Based Concentration. Table Revised by J. Hubbard, Superfund Technical Support Section. Philadelphia, $\mathrm{Pa}$, $<$ http://www.epa.gov/reg3hwmd/risk/riskmenu.htm $>$.

Farag, M.S.; Mohmoud, A.R. and Thakeb, M.M. (2000): Monitoring of some heavy metals pollution in some fish farms. J. Egypt. Vet. Med. Ass.60(3): 39-45.

EOSQC (1993): Egyptian Organization for Standardization and Quality Control. Maximum level for heavy metal concentrations in 
food. Egyptian Specification Standard (E.S.S.) No.2360/1993 pp.5, Ministry of Industry, Egypt.

FAO (1983): Compilation of logal limits for hazardous substances in fish and fishery products. FAO Fishery Circular No.464, pp. 5-100.

Goyer, R.A. (1991): Toxic effects of metals. In: Amdur, M.O.; Douli, J. and Douli, J. and Klansmen, C.D. (Eds.) Caserrett and Doull,s Toxicology: The basic sciense of poisons, Fourth ed. Pergamon Press New York, pp: 623-680.

Gundacker, C. (2000): Comparison of heavy metal bioaccumulation in freshwater mollusks of urban river habitats in Vienna. Environmental Pollution, 110: 61-71.

Gutenmann, W.H.; Bache, C.A.; McCahan, J.B. and Lisk, D.J. (1988): Heavy metals and Chlorinated hydrocarbons in marine fish products. Nutri. Reports Int., 38: 1157-1161.

Henson, M.C.; Chedrese, P.J. (2004): Endocrine disruption by cadmium, a common environmental toxicant with paradoxical effects on reproduction. Exp. Biol. Med. 229: 383-392.

Hodson, P.V.; Whittle, D.M.; Wong, P.T.S.; Porgman, U.; Thomas, R..L.; Chau, Y.K.; Nriaagu, J.O. and Hallett, D.J. (1984): Lead contamination of the great lakes and its potential effects on aquatic biota. Advances Envir. Sci. Tech.14: 335-369.

J.E.C.F.A."Joint FAO/WHO Expert Committee for Additives and Contaminants" (1993): 33, Report: Evaluation of certain food additives and contaminants, WHO Techn., Report Series 837. Genf.

Joint FAO/WHO Expert Committee on Food Additives (2004): Summary of Summary of Evaluations Performed by the Joint FAO/WHO Epert Committee on Food Additives (JECFA, 1956-2003), (First through sixty-first meetings). Food and Agriculture Organization of the United Nations and the World Health Organization, ILSI Press International Life Sciences Institute, Washington, DC.

Labib, H.Y.; Nassar, A.; Ahmed, A. and Shaker, A. (2008): Pollution of Nile fish by some heavy metals at Qena, Upper Egypt. Fourth International Conference for Development and the Enviroment, King Saud Uinv.

Lee, Y.H. and Stuebing, R.B. (1990): Heavy metal contamination in the River Toad, Bufo juxtasper (Inger), near a copper mine in East 
Malaysia. Bulletin of Environmental Contamination and Toxicology, 45: 272-279.

Papagiannis, I.; Kagalou, I.; Leonardos, J.; Petridis, D. and Kalfakaou, $V$. (2004): Copper and zinc in four freshwater fish species from Lake Pamvotis (Greece). Environ.Int., 30: 357-362.

Satarug, S.; Moore, M.R. (2004): Adverse health effects of chronic exposure to low-level cadmium in foodstuffs and cigarette smoke. Environ. Health Perspect. 112: 1099-103.

Stanley, T.O. (2004): Food and Nutritional Toxicology. By CRC Press LLC, Boca Raton London New York Washington, D.C.

Tsoumbaris, P. and Papadopoulou, T.H. (1994): Heavy metals in common food stuff: Quantitative analysis. Bull. Environ. Contam. Toxicl. 53 (1): 61-66.

Underwood, E.J. (1977): Trace elements in human and animal nutrition, $4^{\text {th }}$ Ed. Academic Press, New York, San Francisco, London. A Subsidary of Harcourt Brace Jovanovich Publisher.

US EPA "Environmental Protection Agency" (2004): Region I: New England, Floatable Debris, The Problem. Washington, D.C.: U.S.Environmental Protection Agency http://www.epa.g ov/NE/eco/lis/ccmp/floats.html. July21. (originally published as Long Island Sound Study: Floatable Debris http://www.epa.gov/ord/NRMRL/pubs/625r02009/pdf70.pdf)

Yess, N.J. (1993): U.S. Food and Drug Administration survey of methyl mercury in canned tuna.J.A.O.A.C.Internat.76: 36-38. 